\title{
LEXICAL BUNDLES AND MOVES IN RESEARCH ARTICLE ABSTRACTS OF DIFFERENT DISCIPLINES
}

\author{
Purificación Sánchez Hernández, University of Murcia \\ E-mail: purisan@um.es
}

Received: November 17, 2020

Accepted: November 27, 2020

\begin{abstract}
Much has been published about abstracts as a written genre and less attention has been paid to lexical bundles and "moves" in the abstracts of different disciplines. The purpose of this paper is to select the most common lexical bundles of abstracts in four different fields of knowledge, analyse their structure and function and classify them according to the "moves" they perform. 210 abstracts of 4 different disciplines were collected and the lexical bundles extracted were analysed. The results reveal important differences associated to disciplinary variation in the types of bundles, their structure and function and in the structure of the moves. These finding suggest that disciplinary variation should be considered in academic writing courses.
\end{abstract}

Keywords: Abstracts, academic writing, lexical bundles, moves, disciplinary variation.

Resumen: Se ha publicado mucho sobre el abstract como género, pero se ha prestado poca atención a los "moves" que se registran en los abstracts de diferentes disciplinas. El objetivo de este trabajo es seleccionar los paquetes léxicos en los abstracts de cuatro campos de conocimiento, analizar su estructura y función y la estructura de los "moves". A tal efecto se compilaron 210 abstracts de 4 disciplinas diferentes y se extrajeron y analizaron los paquetes léxicos. El análisis de los resultados revela que existen diferencias importantes asociadas a la variación disciplinaria por lo que refiere al tipo y número de paquetes léxicos, su estructura y función y también en la estructura de los "moves". A la vista de estos resultados se debe prestar atención a la variación disciplinaria en los cursos de escritura académica.

Palabras clave: Resúmenes, escritura académica, paquetes léxicos, movimientos, variación disciplinaria. 


\section{INTRODUCTION}

In scientific discourse, the academic research article plays a fundamental role across different disciplines, since it is the most important form of transmitting scientific research and findings. Defined as "a codification of disciplinary knowledge" (Hyland, 2004: 64) this genre is the culmination of the process of research. Abstracts are a condensed version of the whole RA (Tanko, 2017).

\subsection{Academic Abstracts and moves}

An abstract is a brief description of the entire paper and typically discusses the other sections and has been said to be an article synopsis (Bathia, 1993). Lores (2004:281) defines a research abstract as "an abbreviated, accurate representation of the contents of a document preferably prepared by its author(s) for publication with it". The abstract describes the problem under investigation and the purpose of the study, the participants and general methodology, the findings and the conclusions and implications or applications of the study. In a sense they are short samples of texts where the authors try to make their work attractive and worth reading. Hyland (2015) suggests that abstracts have also an impact in the referees' interest in reviewing and Thompson, (2001) focuses on the ability of writers to develop their argument succinctly and recognisably to their disciplinary audience.

To properly understand how an abstract is organised, research has focused on move structures in abstract, understanding "move" as a stretch of text with a definable rhetorical function (Swales and Feak, 2009). Moves and their linguistic features have been studied and analysed by Dos Santos (1996), Hyland (2004), Lores (2004) Bondi and Lores Sanz (2014). Organization of move categories in the abstract is also important for move analysis approaches. Salager-Meyer (1990) asserts that a well-structured abstract should involve all four structural units (introduction-methods-results-conclusions) in a linear order. However, Dos Santos (1996), Stotesbury (2003), Hyland (2004) Pho (2008) and Jiang and Hyland (2017) propose a five-move structure of Introduction, Purpose, Methods, Results and Conclusion. Gillaerts (2013) suggest that this structure has the advantage of being the most common one and consequently the most useful since comparison can be made across disciplines. However, although the general categories are the same for all disciplines the researchers report results associated to disciplinary variation.

Research has demonstrated the broad disciplinary differences between texts (Hyland 2002, Hyland and Tse 2007, Durrant 2014, Durrant, 2017) and EAP teachers are aware of the problems that arise when considering the "needs" of students of different disciplines who take courses on general academic writing, since each discipline has its own conventions and patterns of use of specific lexical groups, that there is disciplinary variation as far as the use and frequency of some lexical bundles.

\subsection{Lexical Bundles}

Therefore, it is crucial for all the researchers to master the conventions of academic writing. Recent research concludes that lexical bundles, defined as a group of words larger 
than two occurring with a specific frequency in the same register, are an essential component of academic writing. Lexical bundles, have received attention in the past years. Pawler and Syder (1983:216) used the term "lexicalized sentence stem", Scott (1997: 234) refers to them as "clusters", whereas Stubbs (2005) used the term "N-grams". Biber et al (1999) used the expression "lexical bundles" and define the concept as the most frequent recurrent sequences of words in a given register (Biber, 2006).

There are several studies relating the use of lexical bundles with high levels of proficiency in a specific discipline. Biber et al (1999) studied the role of lexical bundles in everyday conversation, Cortes (2004) in research articles, Biber, Conrad and Cortes (2004) compared the lexical bundles found in university textbooks and lectures, Hyland, (2008) in doctoral dissertations and Master's theses, Jablonkai, (2010) in English EU documents and Sánchez (2014) in books and research articles of the same discipline. What all these studies have in common is that they aim to find out tendencies in the use of lexical bundles across different types of texts and registers in order in most cases to help writers use the adequate expression in a text.

Several studies have been carried out on the structure of abstracts in terms of the "moves" present in them and also on the lexical bundles of different disciplines and areas of writing. However, there are not frequent studies combining both things and none reporting frequency, structure and function of lexical bundles associated to moves in the disciplines object of this study. In this work we combine the analysis of structures and functions of the lexical bundles found in the abstracts and their distribution in the "moves".

The most important aims of this paper are:

1) To find out the most frequent lexical bundles in the abstracts of Health Sciences, Life Sciences, Applied Linguistics and Social Sciences.

2) To determine the structure and function of the lexical bundles in the abstracts of the mentioned disciplines and their distribution in the "moves" of the abstracts.

\section{METHODOLOGY}

\subsection{Corpus for This Atudy}

The present study is based on a corpus of research articles of the following areas: Health Sciences, Applied Linguistics, Social Sciences and Life Sciences. All the texts collected have been published in journals online. Journal of the American Medical Association (JAMA), The Modern Journal of Applied Linguistics (TMJAL), Journal of Economics Finance and Administrative Science (JEFAS) and The Journal of Biology and Life Sciences (TJBLS). The abstracts were taken from articles published between 2010-2017.

The abstracts were identified and stored separately. Words were collected from abstracts for each of the different areas. As it is very difficult to get the exact number of words in each study area and there are idiosyncratic differences as far as the number of words allowed in the abstracts in each area of study and the different journals, it was decided to collect 
55 abstracts of each field, what means that in the final count some areas have more words than other since the length of the abstracts depended on the area. Information about the number of words in the abstracts, the number of abstracts and the medium length of the abstract is offered on Table 1 .

\begin{tabular}{|l|c|c|c|}
\hline Study Areas & $\begin{array}{c}\text { Number of words } \\
\text { in the abstracts }\end{array}$ & $\begin{array}{c}\text { Number } \\
\text { of abstracts }\end{array}$ & $\begin{array}{c}\text { Medium length } \\
\text { of the abstract }\end{array}$ \\
\hline $\begin{array}{l}\text { Health Sciences } \\
\text { Medical Sciences }\end{array}$ & 12974 & 55 & 235.89 \\
\hline $\begin{array}{l}\text { Applied Linguistics } \\
\text { The Modern Journal of Applied } \\
\text { Linguistics (MJAL) }\end{array}$ & 10589 & 55 & 192.52 \\
\hline $\begin{array}{l}\text { Social Sciences } \\
\text { Journal of Economics, Finance } \\
\text { and Administrative Sciences } \\
\text { (JEFAS) }\end{array}$ & 10722 & 55 & 194.94 \\
\hline $\begin{array}{l}\text { Life Sciences } \\
\text { The Journal of Biology and } \\
\text { Life Sciences (JBLS) }\end{array}$ & 13348 & 55 & 242.69 \\
\hline Total & 47633 & 220 & \\
\hline
\end{tabular}

Table 1. Number of words in the abstract of the different disciplines and medium length of the abstract

As can be observed the areas with the shortest length of the abstracts are Applied Linguistics and Social Sciences, whereas Life Sciences and Health Sciences show the longest abstracts, but in the end, there are not significant changes, which allows Intra-corpus comparability. Corpora of a similar type were compiled considering that recurrent word combinations can be influenced by the corpus size (Chen and Baker, 2010).

\subsection{Categorisation of Lexical Bundles}

Lexical bundles were identified in the different corpora using a free software tool (http://conc. lextutor.ca/tuples/eng). Only recurrent expressions of four-words were used in this study, in the understanding that they are "more common that 5 or 6-word bundles and offer a wide range of structures and functions" (Hyland 2008b:8). Additionally, most of the studies carried out with lexical bundles have been carried out with 4-word lexical 
bundles, which allows us to establish comparisons with the results reported by Biber and Barbiery, (2007), Biber et al, (2004), Cortes, (2004), Hyland (2008 b), Bychkovska and Lee (2017) and Wright, (2019). In the present study, a lexical bundle should occur in at least three texts, as suggested by Cortes (2004) and Biber and Barbieri (2007). The frequency threshold of 20 times per million words was established for 4-word bundles.

The number of tokens and types of lexical bundles in the abstracts of the 4 corpora is shown in Table 2.

\begin{tabular}{|l|c|c|}
\hline Corpora & $\begin{array}{c}\text { No of lexical bundles } \\
\text { in the abstracts } \\
\text { (Types) }\end{array}$ & $\begin{array}{c}\text { No of lexical bundles } \\
\text { in the abstracts } \\
\text { (tokens) }\end{array}$ \\
\hline $\begin{array}{l}\text { International Journal of Medical } \\
\text { Sciences (IJMS) }\end{array}$ & 11 & 55 \\
\hline $\begin{array}{l}\text { The Modern Journal of Applied } \\
\text { Linguistics (MJAL) }\end{array}$ & 8 & 35 \\
\hline $\begin{array}{l}\text { Journal of Economics, Finance and } \\
\text { Administrative Sciences (JEFAS) }\end{array}$ & 12 & 45 \\
\hline $\begin{array}{l}\text { The Journal of Biology and Life } \\
\text { Sciences (JBLS) }\end{array}$ & 21 & 77 \\
\hline
\end{tabular}

Table 2. Number of tokens and types in the abstracts of the four areas

After comparing the frequencies and patterns across the disciplinary corpora, all the bundles were categorised structurally, in terms of their grammatical types, and functionally, according to their meaning in the texts. In this study Biber et al's (2004) classification for the structural analysis was used. According to this classification there are three main structural types: a) lexical bundles that incorporate verb phrase fragments; b) lexical bundles that incorporate dependent clause fragments; and c) lexical bundles that incorporate noun phrase and prepositional phrase fragments. The different types and subtypes are listed in Table 3. 


\begin{tabular}{|c|c|c|}
\hline Structural types & Sub-types & Sample bundles \\
\hline $\begin{array}{l}\text { 1. Lexical bundles that } \\
\text { incorporate verb phase } \\
\text { fragments }\end{array}$ & $\begin{array}{l}\text { 1a. } 1^{\text {st }} / 2^{\text {nd }} \text { person pronoun }+ \text { VP fragment } \\
\text { 1b. } 3^{\text {rd }} \text { person pronoun }+ \text { VP fragment } \\
\text { 1c. Discourse marker }+ \text { VP fragment } \\
\text { 1d. Verb phrase (with non-passive verb) } \\
\text { 1e. Verb phrase (with passive verb) } \\
\text { 1f. Yes-no question fragments } \\
\text { 1g. WH-question fragments }\end{array}$ & $\begin{array}{l}\text { I'm not going to } \\
\text { And this is a } \\
\text { I mean I don't } \\
\text { Have a lot of } \\
\text { Is based on the } \\
\text { Are you going to } \\
\text { What do you think }\end{array}$ \\
\hline $\begin{array}{l}\text { 2. Lexical bundles that } \\
\text { incorporate dependent } \\
\text { clause fragments }\end{array}$ & $\begin{array}{l}\text { 2a. } 1^{\text {st }} 2^{\text {nd }} \text { person pronoun }+ \text { dependent } \\
\text { clause/fragment } \\
\text { 2b. WH-clause fragments } \\
\text { 2c. If-clause fragments } \\
\text { 2d. To-clause fragment } \\
\text { 2e. That-clause fragment }\end{array}$ & $\begin{array}{l}\text { I want you to } \\
\text { When we get to } \\
\text { If we look at } \\
\text { To be able to } \\
\text { That this is a }\end{array}$ \\
\hline $\begin{array}{l}\text { 3. Lexical bundles } \\
\text { that incorporate } \\
\text { noun phrase and } \\
\text { prepositional phrase } \\
\text { fragments }\end{array}$ & $\begin{array}{l}\text { 3a. Noun phrase with of-phrase fragment } \\
\text { 3b. Noun phrase with other post-modifier } \\
\text { fragment } \\
\text { 3c. Other noun phrase expressions } \\
\text { 3d. Prepositional phrase expressions } \\
\text { 3e. Comparative expressions }\end{array}$ & $\begin{array}{l}\text { One of the things } \\
\text { The way in which } \\
\text { A little bit more } \\
\text { At the end of } \\
\text { As well as the }\end{array}$ \\
\hline
\end{tabular}

Table 3. Structural types of lexical bundles (Biber et al., 2004: 381)

For the functional categorisation, however, the pattern developed by Hyland (2008b) has been employed since the sample shown in this paper was mainly made up of written texts of an academic discipline, in contrast to that of Biber et al. (2004), which was composed of oral and written samples. Hyland (2008b) classified the lexical bundles into the following categories: a) research-oriented; b) text-oriented; and c) participant-oriented. The different types and subtypes are listed in Table 4. 


\begin{tabular}{|c|c|c|}
\hline Functional types & Sub-types & Sample bundles \\
\hline $\begin{array}{l}\text { 1. Research- } \\
\text { oriented - help } \\
\text { writers to structure } \\
\text { their activities and } \\
\text { experiences of the } \\
\text { real world }\end{array}$ & $\begin{array}{l}\text { 1c. Quantification } \\
\text { 1d. Description } \\
\text { 1c. Topic - related to the field of } \\
\text { research }\end{array}$ & $\begin{array}{l}\text { At the beginning, at } \\
\text { the same time, in the } \\
\text { present study } \\
\text { The use of the, } \\
\text { the role of the, the } \\
\text { purpose of the, the } \\
\text { operation of the } \\
\text { The magnitude of } \\
\text { the, a wide range of, } \\
\text { one of the most } \\
\text { The structure of the, } \\
\text { the size of the, the } \\
\text { surface of the } \\
\text { In the Hong Kong,, } \\
\text { the currency board } \\
\text { system }\end{array}$ \\
\hline $\begin{array}{l}\text { 2. Text-oriented } \\
\text { - concerned with } \\
\text { the organisation } \\
\text { of the text and } \\
\text { its meaning as } \\
\text { a message or } \\
\text { argument }\end{array}$ & $\begin{array}{l}\text { 2a. Transition signals - establishing } \\
\text { additive or contrastive links between } \\
\text { elements } \\
\text { 2b. Resultative signals - mark } \\
\text { inferential or causative relations } \\
\text { between elements } \\
\text { 2c. Structuring signals - text-reflexive } \\
\text { markers which organise stretches of } \\
\text { discourse or direct reader elsewhere in } \\
\text { text } \\
\text { 2d. Framing signals - situate arguments } \\
\text { by specifying limiting conditions }\end{array}$ & $\begin{array}{l}\text { On the other hand, } \\
\text { in addition to the, in } \\
\text { contrast to the } \\
\text { As a result of, it was } \\
\text { found that, these } \\
\text { results suggest that } \\
\text { In the present study, } \\
\text { in the next section, } \\
\text { as shown in figure } \\
\text { In the case of, with } \\
\text { respect to the, on } \\
\text { the basis of, in the } \\
\text { presence of, with the } \\
\text { exception of }\end{array}$ \\
\hline $\begin{array}{l}\text { 3. Participant } \\
\text { oriented - these } \\
\text { are focused on the } \\
\text { writer or reader of } \\
\text { the text (Hyland, } \\
\text { 2005) }\end{array}$ & $\begin{array}{l}\text { 3a. Stance features- convey the writer's } \\
\text { attitudes and evaluations } \\
\text { 3b. Engagement features - address } \\
\text { readers directly }\end{array}$ & $\begin{array}{l}\text { Are likely to be, } \\
\text { may be due to, it is } \\
\text { possible that } \\
\text { It should be noted } \\
\text { that, as can be seen }\end{array}$ \\
\hline
\end{tabular}

Table 4. Functional types of lexical bundles (Hyland, 2008b: 13) 


\subsection{Categorisation of Moves}

The five-move structure of Introduction, Purpose, Methods, Results and Conclusion (Jing and Hylands, 2017) has been selected to be used in this work considering that it is the most common and useful to be applied to different disciplines. Table 5 shows the five-move structure applied to the analysis of moves in research articles abstracts

\begin{tabular}{ll}
\hline Move & Function \\
\hline Introduction & $\begin{array}{l}\text { Establishes context of the paper and motivates de research or } \\
\text { discussion }\end{array}$ \\
Purpose & $\begin{array}{l}\text { Indicates purpose, thesis of hypothesis, outlines the Intention of the } \\
\text { paper }\end{array}$ \\
Methods & $\begin{array}{l}\text { Provides Information on design, procedures, assumptions, approach, } \\
\text { data, etc }\end{array}$ \\
Results & $\begin{array}{l}\text { States main finding or results, the argument, or what was } \\
\text { accomplished }\end{array}$ \\
Conclusion & $\begin{array}{l}\text { Interprets or extends results beyond scope of paper, draws Inferences, } \\
\text { points to applications or wider Implications. }\end{array}$ \\
\hline
\end{tabular}

Table 5. Categorization of moves in article abstracts (from Jiang and Hyland, 2017)

\section{RESULTS}

\subsection{Lexical Bundles in Our Corpora}

Only four-word lexical bundles were selected for this study. We found 8 different bundles in the abstracts of The Modern Journal of Applied Linguistics, 21 different bundles in the Journal of Biology and Life Sciences, 12 different bundles in The Journal of Economics, Finance and Administrative Sciences and 11 different bundles in the International Journal of Medical Sciences.

The results obtained for the number and types of lexical bundles of the 55 abstracts in the four disciplines are shown in Table 6. 


\begin{tabular}{|c|c|c|c|}
\hline $\begin{array}{l}\text { The Modern } \\
\text { Journal of Applied } \\
\text { Linguistics (MJAL) }\end{array}$ & $\begin{array}{l}\text { The Journal of Biology } \\
\text { and Life Sciences } \\
\text { (JBLS) }\end{array}$ & $\begin{array}{l}\text { Journal of Economics, } \\
\text { Finance and } \\
\text { Administrative Sciences } \\
\text { (JEFAS) }\end{array}$ & $\begin{array}{l}\text { International } \\
\text { Journal of Medical } \\
\text { Sciences (IJMS) }\end{array}$ \\
\hline $\begin{array}{l}\text { Purpose of this study } \\
\text { (6) } \\
\text { The purpose of this } \\
\text { (6) } \\
\text { Of this study was (5) } \\
\text { This study was to (5) } \\
\text { This study aims to } \\
\text { (4) } \\
\text { The results indicated } \\
\text { that (3) } \\
\text { The findings show } \\
\text { that (3) } \\
\text { This study aims at } \\
\text { (3) }\end{array}$ & $\begin{array}{l}\text { Was found to be (6) } \\
\text { For the first time (6) } \\
\text { The first time in (6) } \\
\text { There was no } \\
\text { significant (5) } \\
\text { The results showed } \\
\text { that (4) } \\
\text { As compared to the (4) } \\
\text { Was no significant } \\
\text { difference (4) } \\
\text { Of the present study (3) } \\
\text { The results showed } \\
\text { significant (3) } \\
\text { The results of the (3) } \\
\text { This study was to (3) } \\
\text { Aims of this study (3) } \\
\text { The aim of this (39 } \\
\text { As a result of (3) } \\
\text { Of this study was (3) } \\
\text { No significant } \\
\text { difference in (3) } \\
\text { At the end of (3) } \\
\text { In the presence of (3) } \\
\text { The present study was } \\
\text { (3) } \\
\text { Compared to the } \\
\text { control (3) } \\
\text { Reported for the first } \\
\text { (3) }\end{array}$ & $\begin{array}{l}\text { The purpose of this (6) } \\
\text { Purpose of this paper (5) } \\
\text { This paper is to (5) } \\
\text { In this paper we (4) } \\
\text { The aim of this (4) } \\
\text { In the case of (3) } \\
\text { It was found that (3) } \\
\text { In this article we (3) } \\
\text { Study was conducted } \\
\text { with (3) } \\
\text { Was found that the (3) } \\
\text { Of this study is (3) } \\
\text { The objective of this (3) }\end{array}$ & $\begin{array}{l}\text { This study was to } \\
\text { (8) } \\
\text { Aim of this study } \\
\text { (8) } \\
\text { The aim of this (8) } \\
\text { Of this study was } \\
\text { (8) } \\
\text { Is one of the (4) } \\
\text { Were found to be } \\
\text { (4) } \\
\text { Significantly higher } \\
\text { than that (3) } \\
\text { Was significantly } \\
\text { higher than (3) } \\
\text { OF this study Is (3) } \\
\text { This study Is to (3) } \\
\text { Of the most } \\
\text { common }\end{array}$ \\
\hline
\end{tabular}

Table 6. Number and types of lexical bundles of the 55 abstracts in the four disciplines 
As expected many of the lexical bundles found in this study are not grammatically complete units, as shown by expressions such as purpose of this study, of this study was, aim of this study etc. what agrees with Cortes (2004) who stated that in academic writing more than $95 \%$ of the lexical bundles were not complete units. "Lexical bundles are identified empirically, rather than intuitively, as word combinations that recur most commonly in a register, and therefore, lexical bundles are usually not complete structural units, but rather fragmented phrases or clauses with new fragments embedded" (Cortes, 2004: 400).

As shown in table 6, the greatest number of types and tokens appear in the Journal of Biology and Life Sciences, in the area of Life Sciences publications, which surpasses those that appear in the other areas.

What these lexical bundle lists have in common is that some bundles related to the objectives and results of the work appear in the abstracts of the four journals. As can be seen, one of the most salient features of these results is that there is no lexical bundle shared by the four publications. However, there seem to be certain expressions or terms associated with some areas of knowledge. For example, the expression "the aim of this" appears associated to IJMS and JBLS, (Life and Health Sciences) whereas "the purpose of this" appears more frequently In MJAL and JEFAS (Humanities and Social Sciences).

It is also remarkable to note that only bundles related to quantities and comparisons appear In Life and Health Sciences journals, whereas no indication of measures or comparisons is given in the other subject areas.

\subsection{Structure and Function of the Bundles}

As far as the structure of the bundles is concerned the results are the following:

\begin{tabular}{|l|c|c|c|c|}
\hline & MJAL & JBLS & JEFAS & IJMS \\
\cline { 2 - 5 } & Tokens \% & Tokens \% & Tokens \% & Tokens \% \\
\hline $\begin{array}{l}\text { 1. Lexical bundles that } \\
\text { incorporate verb phrase } \\
\text { fragments }\end{array}$ & 2365.71 & 3038.9 & 1840 & 1832.72 \\
\hline $\begin{array}{l}\text { 2. Lexical bundles that } \\
\text { incorporate dependent clause } \\
\text { fragments }\end{array}$ & - & - & - & - \\
\hline $\begin{array}{l}\text { 3. Lexical bundles that } \\
\text { incorporate noun phrase and } \\
\text { prepositional phrase fragments }\end{array}$ & 1234.28 & 4761.03 & 2760 & 3767.27 \\
\hline
\end{tabular}

Table 7. Structure of the bundles in the four corpora

As shown in Table 7, there were substantial differences in terms of the structural types of bundles found in the different journals, with the four corpora showing a dissimilar 
distribution of bundles. The highest percentages of bundles in the first group $(65.71 \%)$ appears in the MJAL, whereas the rest of the journals show some similarities in percentages (38.9\% for JBLS, $40 \%$ for JEFAS and $32.72 \%$ for IJMS) The highest percentage of bundles in this group is formed by " $3^{\text {rd }}$ person pronoun + VP fragment" in all journals. This finding appears to confirm one of the main characteristics of scientific writing, that is, the tendency to avoid authorial interpretations. That category is followed by the structure "Verb phrase (with passive verb)", which is usually followed by a prepositional phrase marking a locative or logical relation.

There are no occurrences in the category Lexical bundles that incorporate dependent clause fragments probably due to the very nature of the abstract, where there is no room for detailed explanations on the processes or to show causal relationships.

The last structural category, comprising Lexical bundles that incorporate noun phrase and prepositional phrase fragments, registered the highest number of occurrences (more than $60 \%$ ) in all journals, except in the Modern Journal of Applied Linguistics This is the most common structure overall, which agrees with Biber et al. (1999) who reported that this category contains one of the largest number of bundles in academic prose, since more $\tan 60 \%$ of the common bundles consist of noun phrase expressions (e.g. The nature of this) or a sequence that bridges across two prepositional phrases (e.g. as a result of)" and also with the finding reported by Cortes (2004: 404), who states that "academic writing is structurally more phrasal in nature than conversation".

The most common structure in this category in our corpora is "noun phrase with ofphrase fragment", followed by "Prepositional phrase expressions". There are also some "comparative expressions" in the JBLS and IJMS, probably due to the very nature of these disciplines, where experiments require measurements and comparisons.

The structure of the bundles has been so far analysed and now we turn to analyse their functions in order to better understand their role in the academic discourse of the areas selected. The results are shown in table 8 .

\begin{tabular}{|l|c|c|c|c|}
\hline & MJAL & JBLS & JEFAS & IJMS \\
\cline { 2 - 5 } & Tokens $\%$ & Tokens $\%$ & Tokens $\%$ & Tokens \% \\
\hline 1. Research oriented & 1234.28 & 5166.23 & 1942.22 & 1323.63 \\
\hline 2. Text-oriented & 2365.714 & 2633.76 & 2657.77 & 4276.36 \\
\hline 3. Participant oriented & - & - & - & - \\
\hline
\end{tabular}

Table 8. Functions of the bundles in the four corpora

Functional bundles have a wide pedagogical reach as they can be selected to present important and classical EAP points, such as expressing comparison and contrast, introducing topics, and drawing conclusions. Important differences have been found in the function of lexical bundles across registers as suggested by Biber and Barbieri (2007:265) who reported that in the case of ESP it is necessary to consider each register "on its own terms" in order 
to provide an accurate description of the function of the bundles. It is also important to note that bundles were classified into the function they most often perform, but this does not mean that they can only be used solely in that function. (Biber, Conrad \& Cortes, 2004).

Research-oriented bundles provide information about the research by indicating location in time and place, procedure quantification, description and topic of the research.

In our corpora the highest occurrences of research-oriented bundles are given in the JBLS where two thirds of the bundles belong to that category, as expected in an experimental discipline. These results coincide with Sanchez (2014) who reported similar results considering that in a discipline like Biology, deeply rooted in scientific thought, the emphasis is on the empirical over interpretation.

The most remarkable difference between the four corpora lies in the text-oriented category, which help writers organize the texts and are twice as frequent in the abstracts taken from the International Journal of Medical Sciences (IJMS) as in the Journal of Biology and Life Sciences (JBLS).

Text-oriented bundles provide information about transition signals (additive or contrastive links between elements), resultative signals (mark inferential of causative relations), structuring signals (text-reflexive markers to organize discourse) and framing signals (situating arguments) are considered characteristic of "soft knowledge fields (Applied linguistics and marketing)" (Hyland 2017:4), where persuasion is more explicitly interpretative and less empiricist. Our corpora register high occurrence of text-oriented bundles in MJAL, JEFAS and IJMS with the highest proportion. The low occurrence in JBLS of these types of bundles could be a proof of empiricism in the way discourse is organised in that corpus.

Participant oriented bundles focus on the reader-writer of the text, the ways in which writers evaluate the facts they are dealing with and the ways writers address readers. No occurrences take place in our corpora, as expected, since the very nature of abstracts prevent the writers from guiding the readers to the text and giving them clues to interpret the facts.

\subsection{Categorization of Moves}

In order to associate the different bundles obtained with the moves in abstracts, an initial classification was made. To obtain more reliable results, a second researcher was asked to classify the bundles in the different moves. The results of both coincided by $90 \%$. In those cases, in which there was no agreement because a bundle could appear in two different moves, the context in which the bundles had been produced was reviewed.

The final results are shown in Table 9. 


\begin{tabular}{|l|c|c|c|c|c|}
\hline & Introduction & Purpose & Method & Product & Conclusions \\
\hline MJAL & & $6(75 \%)$ & & $2(25 \%)$ & \\
\hline JBLS & & $6(28.57 \%)$ & & $14(66.66 \%)$ & $1(4.77 \%)$ \\
\hline JEFAS & & $8(66.66 \%)$ & $1(8.33)$ & $3(25 \%)$ & \\
\hline IJMS & $2(18.18 \%)$ & $6(54.54 \%)$ & & $3(27.27 \%)$ & \\
\hline
\end{tabular}

Table 9. Classification of the moves in lexical abstracts

The 220 abstracts contained 52 lexical bundles associated to moves with 50\% containing lexical bundles of purpose move, $42.30 \%$ of product move, $3.84 \%$ of introduction move and $1.92 \%$ of lexical bundles both in the conclusion and method move.

As can be seen, the moves all the abstracts have in common are those related to "purpose" and "product". In the case of the purpose, the percentages are high in general except in the case of the JBLS; the same happens in the case of product, where all the journals except JBLS keep low percentages of occurrences. The only journal which presents bundles in the move of conclusions is again the JBLS, whereas IJMS is the only one which presents bundles in the move of introduction.

As shown in the data offered, the only journal that registers moves in the field of product is JBLS. We cannot extend this conclusion to the entire area of Biology and Life Sciences, because it may be that this trend is idiosyncratic to that journal, so it would be useful to continue research in this field.

The first move, Introduction, serves to establish the context of the paper, that is, to contextualize the study. Accordingly, authors should start the abstract with the introductory move. However, in our study, instances of introductory move have only been found in the IJMS with a very low proportion. In the rest of the journals under study the authors have started with the Purpose move, what agrees with the results reported by Abarghooeinezhad and Simin (2015) who described very low occurrences of Introduction moves in the abstracts analysed. In our case only $18.18 \%$ of the moves registered in one single area (IJMS) can be classified as Introduction moves.

The second move, Purpose, indicates purpose and outlines the intention of the paper. This is move together with the Product that registers more occurrences and occur in all the abstracts written in the four journals, what agrees with the findings described by Van Bonn and Swales (2007) who reported that all the abstracts analysed included the purpose move. Therefore, the purpose move seems to be a compulsory move in the abstract genre.

The third move, method, provides information on design, procedures, assumptions, approach, data, etc. In our study there are not lexical bundles associated to this move, except in the case of JEFAS, where only an occurrence has been found. This is a compulsory move in any research abstract. However, as Jiang and Hyland (2017) report not all the abstracts they analysed included this move. In fact, they state that soft disciplines (Applied Linguistics and Marketing) are more prone to include this movement than hard disciplines. 
As for the fourth move, used to state main finding or results, the argument, or the description of what was accomplished, all the abstracts contain this product move. Our findings coincide with those reported by Van Bonn \& Swales (2007) who suggest that all the authors include this move in their abstract to promote their research to the same field community.

The conclusion move is used by writers to interpret or extend their results beyond the scope of the paper, to draw inferences or to point to applications or wider implications.

In the present study, only 1 instance of lexical bundles pertaining to the conclusion move was found in the Journal of Biology and Life Sciences, that is the journal which registers more lexical bundles in the different moves.

Conclusions

The abstract is a very important academic genre, "crucial to the construction of knowledge by allowing readers to filter the flow of information available and enabling writers to endorse their accompanying article" (Hyland, 2017: 11). Since it is sometimes the only part of the article that is accessed to decide whether or not reading the rest of the article, authors must consider take special care in preparing it respecting the conventions. However, the abstract is not a universal genre and has disciplinary variability as we have seen in the present work where lexical bundles have been analysed in abstracts of different fields of knowledge and journals.

There are some differences as far as the number of types and tokens in the four corpora, being the JBLS where more types and tokens have been registered. There are some lexical bundles which could be idiosyncratic of some areas. "The purpose of this" appears in the MJAL and JEFAS (soft-knowledge disciplines) whereas "The aim of this" is registered in the JBLS and the IJMS as well as bundles of comparison and quantities only present in the Life and Health Sciences Journals.

As far as the structure of the bundles is related, the JBLS, JEFAS and IJMS present similar percentages in the 1) "Lexical bundles that incorporate verb phrase fragments" and 3) "Lexical bundles that incorporate noun phrase and prepositional phrase fragments". However, the MJAL journal behaves completely differently from the other journals analysed, showing percentages much higher than the others in the first category and much lower in the third category.

One of the most striking features of these bundles is the difference seen in the use of research-oriented bundles in JBLS and the rest of the journals. In the abstracts of JBLS, $66.23 \%$ of research oriented lexical bundles are registered and 33.76 text oriented, whereas in the rest of the journals the percentages are reversed. MJAL, JEFAS and JMS record many more text-oriented lexical bundles and less research oriented.

All analysed abstracts present lexical bundles in the purpose and results moves, whereas instances of the introductory move and the conclusion move have only been found in the IJMS and the JBLS respectively. Both journals include longer abstracts (235.89 and 242.69 respectively) than MJAP and JEFAS (192.52 and 194.94, respectively). These findings emphasize pedagogical implications of these formulaic expression of EAP practitioners.

Abstracts function "as advance indicators of the structure and content" of the complete research (Swales, 1990:179). After extracting the four-word lexical bundles of abstracts pertaining to four different fields of knowledge, analysing their structure and function and 
their role in the moves, we have shown that there is disciplinary variation in the use of lexical bundles, in way the abstracts are structured and the moves are organized. In some fields and journals, for example, more importance is given to the objectives of the work than to the results and vice versa. As Berkenkotter and Huckin (1993:50) report, abstracts "reveal much about a discourse community". So, some linguistic features of paper abstracts, such as the most common lexical bundles used and the moves they are used for, could be incorporated into academic writing courses.

\section{REFERENCES}

Abarghooeinezhad, A. \& Simin, S. 2015. "Analyses of Verb Tense and Voice of Research Article Abstracts in Engineering Journals". International Letters of Social and Humanistic Sciences 47: 139-152.

BathiA, V. K. 1993. Analysing genre: Language use in professional settings. London: LONGMAN.

Bekenkotter, C. \& Huckin, T. N. 1993. "Rethinking Genre from a Sociocognitive Perspective". Written Communication, 10(4): 475-509. https:/doi.org/10.1177/0741 088393010004001.

Biber, D., Johansson, S., Leech, G., Conrad, S. \& FINNEGAN, E. 1999. The Longman Grammar of Spoken and Written English. London: Longman.

BIBER, D. 2006. University Language: A Corpus-based Study of Spoken and Written Registers. Amsterdam: John Benjamins.

Biber, D. Conrad, S. \& Cortes, V. 2004. "If you look at... Lexical bundles in university teaching and textbooks". Applied Linguistics, 25(3): 371-405.

BIBER, D. \& BARBIERI, F. 2007. "Lexical bundles in university spoken and written registers". English for Specific Purposes, 26: 263-286.

Bondi, M. \& LoRes Sanz, R. 2014. Abstracts in Academic Discourse: Variation and Change. Berlin: Peter Lang.

Bychkovska, T., \& LeE, J. J. 2017. "At the same time: Lexical bundles in L1 and L2 university student argumentative writing". Journal of English for Academic Purposes, 30: $38-52$.

CORTES, V. 2004. "Lexical bundles in published and student disciplinary writing: Examples from history and biology". English for Specific Purposes, 23, 397-423.

Chen, Y. \& BAKeR, P. 2010. “Lexical Bundles in L1 and L2 Academic Writing”. Language Learning \& Technology, 14 (2): 30-49.

Dos SAntos, M. B. 1996. “The textual organization of research paper abstracts in applied linguistics" Text, 16(4): 481-499.

Durrant, P. 2014. "Discipline and Level Specificity in University Students' Written Vocabulary". Applied Linguistics, 35(3): 328-356. 
Durrant, P. 2017. "Lexical Bundles and Disciplinary Variation in University Students' Writing: Mapping the Territories". Applied Linguistics, 38 (2): 165-193.

Gillaerts, P. 2013. "Move analysis of abstracts form a diachronic perspective: A case study". Of butterflies and birds, of dialects and genres. Eds. N.L. Johannesson, G. Melchers, and B. Björman. Stockholm: Acta Universitatis Stockholmiensis. 49-60.

Hyland, K. 2002. “Specificity revisited: How far should we go now?” Journal of English for Specific Purposes, 21(4): 385-95.

Hyland, K. 2004. Disciplinary Discourses: Social Interactions in Academic Writing. Ann Arbor: UMP.

Hyland, K. 2008a. "Academic clusters: Text patterning in published and postgraduate writing”. International Journal of Applied Linguistics, 18(I): 41-62.

HyLAND, K. 2008b. “As can be seen: Lexical bundles and disciplinary variation”. English for Specific Purposes, 27(I): 4-21.

Hyland, K. 2015. Academic Publishing: Issues and challenges in the construction of knowledge. Oxford: OUP.

Hyland, K \& TsE, P. 2007. “Is there an 'academic vocabulary'?” TESOL Quarterly, 41(2): 235-253.

JABLONKAI, R. 2010. "English in the context of European integration: A corpus-driven analysis of lexical bundles in English EU documents". English for Specific Purposes 29(4): 253-267.

JIANG, K. \& HYLAND, K. 2017. "Is academic writing becoming more informal?" English for Specific Purposes, 45, 40-51.

LORES, R. 2004. "On RA abstracts: From rhetorical structure to thematic organisation". English for Specific Purposes, 23(3): 280-302.

Pawley, A. \& Syder, F. 1983. "Two puzzles for linguistic theory: nativelike selection and nativelike fluency". Language and Communication. Eds. Richards, JC. Schmidt, R.W. London: Longman. 191-226.

Pно, P. D. 2008. "Research article abstracts in applied linguistics and educational technology: A study of linguistic realizations of rhetorical structure and authorial stance". Discourse Studies, 10(2): 231-250.

SALAGER-Meyer, F. 1990. "Discoursal flaws in medical English abstracts: A genre analysis per research and text type" Text, 10, 365-384.

SANCHEZ, P. 2014. "Lexical bundles in Biology: Differences between books and research articles”. RESLA, 27(2): 492-513.

Swales, J. M. 1990. Genre Analysis: English in Academic and Research Setting. Cambridge: CUP.

Swales, J. \& Feak, C. 2009. "Abstracts and the writing of abstracts" John M. Swales. Christine B. Feak (Michigan series in English for academic and professional purposes). Ann Arbor: University of Michigan Press. 
Scott, M. 1996. Wordsmith Tools 4. Oxford University Press.

Stotesbury, H. 2003. "Evaluation in research article abstracts in the narrative and hard sciences". Journal of English for Academic Purposes, 2: 327-341.

STUBBS, M. 2005. "Conrad in the computer: examples of quantitative stylistic methods". Language and Literature. 14(1): 5-24.

TANKo, G. 2017. "Literary research article abstracts: An analysis of rhetorical moves and their linguistic realizations". Journal of English for Academic Purposes, 27: 42-55.

Thomson, G. 2001. "Interaction in academic writing: Learning to argue with the reader". Applied Linguistics, 22(1): 58-78.

VAn Bonn, S. \& Swales, J. M. 2007. "English and French journal abstracts in the language sciences: Three exploratory studies". Journal of English for Academic Purposes, 6(2): 93-108.

Wright, C. 2019. "Developing Communicative Competence in Adult Beginner Learners of Chinese" Eds. Shei C; McLellan Zikpi ME and Chao D. L. The Routledge Handbook of Chinese Language Teaching. Oxon, UK: Routledge, 134-148. 